\title{
Curated Ruins and the Endurance of Conflict Heritage
}

\author{
Gabriel Moshenska \\ UCL Institute of Archaeology, UK
}

Architectural ruins created by bombing, artillery, and fire are a common feature of post-conflict urban and extra-urban environments, serving as stark reminders of the material impact of warfare and violence. Over time most of these ruins are either restored, demolished, or reclaimed by nature. This paper examines another, more unusual category: sites that are carefully maintained in a freshly ruined state, suggesting that their destruction was more recent than it actually was. These sites - most often configured as memorials - raise interesting questions about memorialization, conflict heritage, authenticity, ethics, and whether or not there is a 'natural' lifespan or lifecycle for architectural ruins. To illustrate this argument I will draw on case studies of the Frauenkirche in Dresden, Germany, and the ruins of Oradour-sur-Glane in France.

KEYWORDS conflict heritage, conservation, cultural capital, Dresden, Oradoursur-Glane, war memorials

\section{Introduction}

Years ago I heard a story from a friend who worked as a relief worker in parts of the former Yugoslavia. He told me about families who had returned to the villages and towns from which they had been 'ethnically cleansed' by their neighbours, and found that their homes had been demolished with explosives to prevent their ever returning to them. My friend told me that the people built new houses close to the old ones, but that they neither cleared the ruins nor attempted to rebuild the old homes. Instead, many families worked hard to remove all the plants that had grown over the ruined homes, and having cleared the ruins to their original state they regularly weeded them. They did this so that the ruins of their homes would look - to them, to their neighbours, and to the rest of the world - as if the genocidal processes of demolition had occurred in recent days or weeks, although by that time they were more than a decade in the past.

My first, visceral response to this story of curated ruins was a mixture of disgust, anger, and general discomfort: anger at what I took to be an attempt to manipulate 
people's emotions; disgust at the passive-aggressive flaunting of ruins 'like beggars who exhibit their sores for money' (Auden, I962: 99); and discomfort at the rejection of what I unthinkingly regarded as the material manifestation of psychologically normal, healthy processes of recovery from trauma. After some critical reflection (over, I must confess, several years) my more considered responses to these ruins were to rebuke myself for a lack of empathy, and to marvel at the ruin curators' mastery of the semiotics of victimhood and the symbolic economy of cultural and political capital that it entails. I was wrong to think that there is a 'natural' life path for the ruins of violent conflict, but there is certainly an unwritten set of conventions that merit further exploration.

In this paper I take a more considered approach to curated ruins and pose a number of questions. My aim is to challenge uncritical, conventional attitudes towards the material traces of violent conflicts and their implications in the fields of conservation, post-conflict reconstruction and recovery, and the commemoration and memorialization of conflicts. I am particularly interested in exploring the role of ruins in the generation of cultural and political capital, and how the different management trajectories of ruined sites serve the socio-political interests of different parties. To examine these issues in detail I am going to use two well-known illustrative case studies: the ruined village of Oradour-sur-Glane in France, and the reconstructed Frauenkirche in Dresden, Germany. Both of these places have served as symbols of national suffering and loss, both have been (at times) curated or 'cultivated' ruins, and both have been subjected to controversial building programmes: conservation at Oradour; reconstruction in Dresden (Eshel, 20IO: I35). I use the term 'curation' as a shorthand for control and care of heritage resources, whether by professionals or by other stakeholders. In relation to ruins I use it to refer more specifically to a strategy of low-impact conservation aimed at maintaining architectural ruins in a fragile stasis.

\section{The ruins of the Second World War in Europe}

Ruins are not new: for as long as there have been buildings there have been ruins; the results of violence, accident, and natural disaster. Ruins have also attracted all kinds of curiosity and fascination as disordered spaces, aesthetic spaces, and as symbols of disaster and loss. Ruminating on ruins has also proved to be a productive strand of medium-weight academic pontificating across a range of disciplines, most recently within heritage studies (e.g. Moshenska, 2009; 20I4). A considerable number of these studies have focused in particular on the ruins and stages of reconstruction of just one city - post-1945 Berlin — which was memorably dismissed by Brecht as 'the heap of rubble near Potsdam' (in Tumarkin, 2005: 175). The ruins of Berlin and other cities during and after the Second World War inspired filmmakers, photographers, artists, and writers to explore past, present, and future themes of ruination and destruction (for more on the cultural life of ruins I recommend Dillon, 20I4; Roth, et al., I997; and Woodward, 2002). To understand the life stories of ruins it is worth looking in more depth at the ruins left in the aftermath of the Second World War, and the various strategies for clearing, repairing, and rebuilding them.

Rose Macauley's I953 study Pleasure of Ruins drew explicit connections between the romantic ruins of the distant past, and the (then recent) bombsites left in the 
wake of the Second World War. More than any other conflict before or since, the Second World War saw the devastation of towns and cities and the creation of ruins on a vast scale. The most decisive factor was undoubtedly the introduction of area bombing, targeting entire urban areas without the ability or, later, the will to focus more carefully on specific targets. The German bombing of British cities in I940-4I set the scene for this warfare in western Europe, while British and American bombing of continental cities grew more slowly, finessing strategies and technologies such as fire-bombing and pathfinder bombing, and reaching a peak in the closing stages of the European war with the destruction of Dresden (Schaffer, 2009). At the same time, the German invasion of the Soviet Union, and later the advance of Allied land forces into Germany in the last months of the war, saw the use of massive artillery bombardments of urban areas, most notably by the Soviet Red Army in its advance into Berlin (Keegan, I989).

Without doubt the greatest part of the destruction wreaked across European and, later, Japanese cities was the result of air warfare and (to a much lesser extent) artillery (Lindqvist, 200I). However, there were also entire towns and districts destroyed more systematically and deliberately: the Jewish ghetto in Nazi-occupied Warsaw was demolished building by building to root out the resistance fighters trying to prevent the liquidation of the ghetto population. The Czechoslovakian village of Lidice and the French village of Oradour-sur-Glane were both burned and their populations massacred by German forces in retaliation for resistance activities: Lidice was reduced to rubble by demolition teams (de Keizer, 2013). Perhaps the largest-scale demolition of this type was that of Warsaw in 1944, when resistance forces in the city rose up against the Nazi occupiers, more than a year after the ghetto uprising. In the aftermath of the failed insurrection the German troops destroyed thousands of buildings using flamethrowers and explosives, targeting sites of cultural and historic significance alongside homes and businesses, and leaving little more than a tenth of the city standing (Davies, 2006). When the Second World War in Europe drew to a close in May 1945 great swathes of the capital cities, towns, and villages of the Continent lay in ashes and rubble.

\section{The lives of ruins}

The ruins of Europe presented a number of challenges to the post-war world. Some of these challenges were practical, such as the need to re-home millions of refugees, returning soldiers, and the homeless to avoid epidemics, starvation, and the sociopolitical challenges of large populations on the move through a continent whose new borders were rapidly solidifying. Other challenges were more ideological and utopian: the ruins of Europe were a blank canvas for progressive-minded architects and planners like Patrick Abercrombie who imagined the modernist cities of the future (Tiratsoo, 2000). Most of these plans were stymied by another challenge: the poverty of most of the combatant nations, and the enormous cost of rebuilding in any form in the immediate post-war years. Finally, there were the logistical challenges: the rubble that covered the cities, whether measured in tons or cubic metres, ran into the tens or hundreds of millions - post-war Berlin alone was said to contain around 75 million cubic metres of detritus (Tumarkin, 2005: 175). On an individual scale, 
there are a number of different approaches to post-conflict ruined buildings, which can be roughly summarized as follows:

- Removal: the clearing or levelling of the site, including the destruction of partially standing or unsafe structures, leaving space for the construction of new buildings.

- Recycling: the use of ruins (and, therefore, their gradual erosion) as a source of recycled building materials, whether dressed stone, brick, or other elements.

- Repair: some buildings can be returned to usable conditions where the damage is superficial or non-structural, such as the loss of wooden roofs, floors, and fittings of an otherwise stable stone or brick structure.

- Reconstruction: even when a building has sustained serious structural damage this can sometimes be repaired, to the point that substantial parts of the structure are non-original.

- Replication: in some cases where a building has been completely or almost completely annihilated, it can be replicated (at least in its external form) from the original plans or using drawings and photographs.

- Replacement: where the building served a specific purpose in its location, it may be replaced with a similar but non-identical structure with the same function.

- Curation: finally, the devastated structure can be maintained in its static, ruined state through careful conservation and stabilization. This is often done for the purpose of turning the ruin into a memorial.

With regard to the category of curation, I think it is worth distinguishing two types of curated ruin: 'clean' and 'dirty'. Clean ruins are those such as old Coventry Cathedral or Christ Church Greyfriars in central London, preserved as roofless standing structures: broken or burnt walls and columns laid out as pleasant open spaces with benches and plants (Lambourne, 200I: I79-83). They are 'clean' because the rubble and debris have been cleared away. In contrast, 'dirty' ruins are those where the broken fragments of the building have been left heaped up, usually within the footprint of the original structure. This is not to say that 'dirty' ruins are more authentic or less carefully curated that 'clean' ones: in fact it is often quite the opposite, as 'dirty' ruins are far more complicated to maintain.

The patterns of post-I945 urban renewal varied considerably across Europe, and there were certain exceptional episodes such as the large-scale rebuilding of Warsaw. Time-spans, national policies, and other factors may have varied, but nonetheless there are general patterns that emerge in the treatment of ruins in Europe post-I945. In general terms, distinctions can be made between different categories of ruins:

- Infrastructure: ruined structures related to the maintenance of utilities such as electricity, gas, water, and sewers are likely to be repaired, reconstructed, or replaced, provided that they are still needed. The timeframe for these processes will be short, as they are vital services.

- Residential and related: the ruins of houses, apartment buildings, and small businesses of various kinds are likely to be removed or repaired, depending on their condition, and may be replaced or used as sources of recycled building materials. These processes can last for years or even decades after the conflict ends. 
- Industrial and related: where the industry in question is deemed economically or militarily vital, structures can be repaired, reconstructed, replicated, or replaced with startling speed. Otherwise, the ruins are likely to be treated like residential ruins.

- Landmarks and prestigious buildings: these ruins are most likely to be repaired or reconstructed or, in a few cases, replicated, particularly when they are symbols of local, national, ethnic, or religious identity. In terms of time, landmark buildings are usually dealt with relatively rapidly.

- Churches and places of worship: ruins of this type are most often repaired, reconstructed, or replaced with more manageable modern versions. In a few cases where they are also landmarks (as defined above), they may be replicated. However, ruined churches are the buildings most likely to be curated in their ruined forms - either 'clean' or 'dirty' — for extended periods of time, often as memorials to the conflict.

The use of curated ruins as memorials is an intriguing cultural practice that has spread around the world since the Second World War. The Genbaku Dome in Hiroshima is a particularly famous and iconic example, and more recently the ruins of the World Trade Centre in New York briefly served this purpose before the redevelopment of the site began (Gutman, 2009; Meskell, 2002). However, as Rico (2008) and others have noted, the contested nature of monuments that mark episodes of violent conflict has often presented challenges to their preservation and protection, due in part to the dominance of nation states in heritage policy and practice, including on international levels.

To examine the use of curated ruins as memorials in more depth I want to look at the life histories of two well-known sites: the Frauenkirche in Dresden, destroyed by bombing in February 1945; and the town of Oradour-sur-Glane in France, destroyed as part of a massacre by German troops in June 1944 .

\section{The Frauenkirche, Dresden}

The Allied bombing of Dresden in mid-February 1945 is one of the most controversial and historically disputed episodes of the Second World War. Dresden was an architecturally attractive city that had hitherto avoided serious bomb damage, and the population was swelled by refugees fleeing the advancing Russian forces. Several thousand tons of explosive and incendiary bombs were dropped in and around the city centre, creating a firestorm that engulfed thousands of buildings, reaching temperatures of 1500 degrees. The total number of casualties from the raids is estimated at $25,000-30,000$. In the years after the war the military necessity of the raids have been frequently questioned and debated, as has the status of the attack as a possible war crime (Grayling, 2006; Taylor, 2005). The debate has been muddied by far-right historians' deliberate misinterpretation of documents to exaggerate the casualty figures by a factor of ten.

The destruction of the Frauenkirche has come to symbolize the bombing of Dresden. The eighteenth-century Protestant church had stood in the heart of the city for two centuries, its stone dome dominating the skyline. The church survived the first two days of bombing but was weakened by the firestorm and collapsed in 


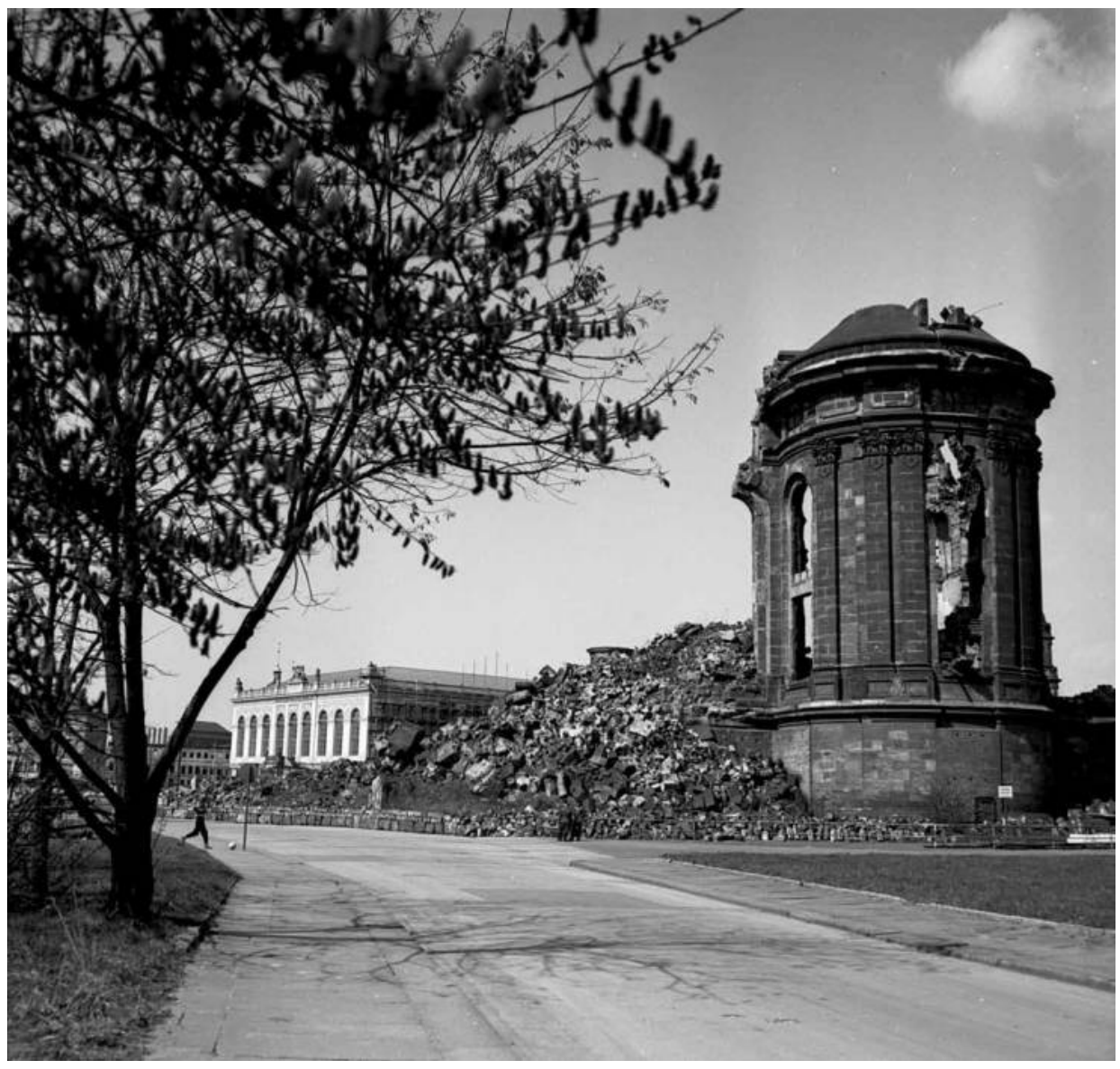

FIGURE 1 The ruins of the Frauenkirche in the 1970s, before restoration.

Source: Erich Braun, Wikimedia Commons

on itself on $5_{5}$ February, leaving only fragments of wall standing above the rubble. In the period after the war Dresden fell within the Soviet-controlled zone, later the German Democratic Republic (DDR), and the city was substantially rebuilt. Most of the bombed areas were cleared, but the Frauenkirche was left in ruins (Figure I).

The remains of the church were what I have categorized as 'dirty' ruins: apart from a few wall fragments standing above the rubble, the remains of the building were an untidy heap of burnt stones, with weeds growing amongst them. For the politicians who controlled the site, and the DDR in general, the ruins of the Frauenkirche served as a rhetorical tool for emphasizing the brutality of the Capitalist Allies (Britain and the United States) in the Second World War, and for highlighting the suffering of ordinary working-class Germans. This supported the national narrative within the DDR that the German people as a whole were victims (rather than participants or beneficiaries) of the Nazi state. In the years leading up to German reunification and the end of the Cold War, the ruins of the Frauenkirche became the focus for antigovernment protests in the DDR, serving as a memorial for peace and anti-militarism 
(James, 2006). The different meanings ascribed to the ruins is an indication of the political complexity of war memorials and iconic memorial sites in general, which has been explored by Pierre Nora (1989), Jay Winter (2006), and others.

The project of German reunification (or Wiedervereinigung) in the r99os heralded a programme of material reconstruction alongside efforts at social and cultural retrieval and rejuvenation. Urban areas such as central Berlin and specific sites and monuments around the country began to be rebuilt as symbols of the new German identity: postpostnationalist, a nation once again proud of its identity (Huyssen, 2003; Jordan, 2006). The reconstruction of Dresden's Frauenkirche was one of the most high profile of these reconstruction campaigns, and in the process brought to light the tangled set of meanings that the ruins embodied, and the equally problematic significances of the act of rebuilding.

The campaign for reconstruction began in Dresden in the I980s but took off following reunification, with the foundation of the Society to Promote the Reconstruction of the Church of Our Lady, and with an intense fundraising effort including the notable involvement of supporters in Britain and the United States (ultimately around half of the budget would come from these sources) (Taylor, 2005). Donors included a former US airman who took part in the bombing of Dresden, while the craftsman who created the steel, copper, and gold cross at the top of the restored church was the son of an RAF pilot who also took part in the raids (Tumarkin, 2005: 175).

Some of the publicity for the campaign drew upon the common metaphor of ruins as wounds, asking donors to 'Help heal one of the most painful wounds in the heart of Europe' (in James, 2006: 254). From the start there was overwhelming support for the reconstruction in Dresden, with particular emphasis on themes of national and local healing and moving forward. As was common in German civil society at this time, the reconstruction became the subject of considerable debate and reflection: part of the ongoing post-I945 project of Vergangenheitsbewältigung or 'working through the past'.

However, there was also a strand of resistance to the reconstruction amongst some commentators and local residents. Most were motivated by an appreciation of the church in its 'dirty ruin' form as a powerful monument to the bombing of Dresden, and questioned whether the reconstructed church would have the same symbolic impact. A few suggested that the reconstruction was an act of erasure, moving towards deliberately forgetting an uncomfortable past (James, 2006).

In its restored form, the Frauenkirche incorporates the surviving structural elements on two of its sides, as well as substantial quantities of the original building stones amidst the new material. The clearing of the ruins was described as 'archaeological', as the aim was not only to empty the site of rubble, but to retrieve, identify, and archive as many original stone elements as possible, in preparation for the reconstruction (James, 2006). The burnt surfaces of the ruined portions and the recycled stones contrast with the clean, white new stones, giving a stark visual reminder of the destruction (Figure 2).

In his analysis of the campaign and programme of reconstruction, James focuses on the symbolism of the act of rebuilding, as well as of the rebuilt structure itself:

The reconstruction carries out $[\ldots]$ a symbolic act of identity (re)construction through a dramatic performance of recovery. This performance has two main dimensions, which I associate with two forms of fetishism. First, in what I call 'monumental fetishism,' the reconstruction performs a conjuring of the nation in the form of a monument to German 


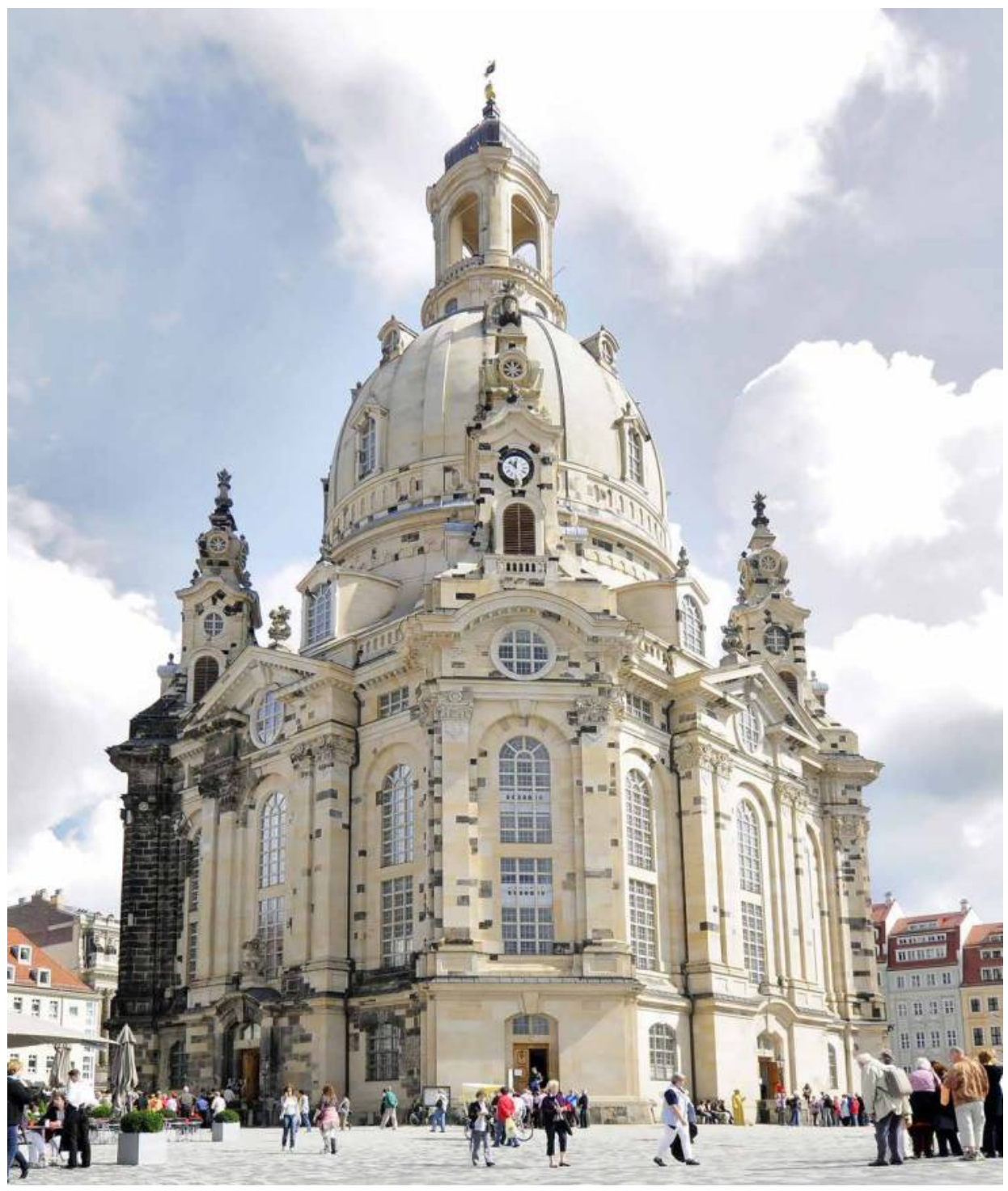

FIGURE 2 The rebuilt Frauenkirch showing the surviving sections and reused material in darker colours.

Source: Josef Beyer, Wikimedia Commons

heritage $[\ldots]$ Second, the core fantasy of the project is simply that the Frauenkirche has returned - that loss can be undone. (James, 2006: 248)

I would add that the removal of the 'dirty ruin' of the Frauenkirche served a number of other purposes, including removing an aesthetically displeasing and politically problematic object from the city centre. The ruins' association with the Nazi era and with the DDR allowed them to be fitted into the narrative of healing that is common with sites of this kind: namely, that there is a natural lifecycle for ruins, and that their 
removal or rebuilding can mark an end to eras of collective performances of pain and guilt. The critique of this natural lifecycle model lies at the heart of this paper, so it is worth noting the resistance - albeit limited - to the Frauenkirche reconstruction project. For the critics, the reconstruction robbed the city of a memorial and material witness to the horrors of the bombing and the heritage of the Third Reich. These conflicting viewpoints on Nazi heritage can be seen in the slogans: the call to 'heal one of the most painful wounds' contrasts with the Aktive Museum in Berlin, whose I980s excavations of ruined Nazi buildings carried the slogan 'the wound must stay open' (James, 2006; Moshenska, 2010).

\section{Oradour-sur-Glane}

Amongst the most famous large-scale curated ruins is the old town of Oradour-surGlane in the Limousin region of France. The town was the site of an infamous massacre: 642 people, almost the entire population, were murdered by a unit of the Waffen SS as a reprisal for resistance activity in the area. The massacre took place on Io June I944, just days after the D-Day landings in Normandy. The male population were imprisoned in barns before being shot and burned, while the women and children were confined in the town church which was then burned. Of the small number of survivors, most were seriously wounded. After the killings the town was systematically burned (Farmer, I999).

In the aftermath of the Second World War the survivors of the massacre and other residents of the town who had been absent on the day of the killing decided to leave the ruins untouched and to build a new town nearby. A memorial to the massacre was installed in the old town cemetery, incorporating within it some of the burnt remains of the victims. This memorial became the focus of annual commemorations by survivors and relatives. In its transformation into a memorial site, the ruins were left largely intact. Discreet plaques were placed outside houses listing the residents and their occupations, and a small museum was erected to display a number of smaller and more fragile personal objects. Otherwise the site was allowed to remain in the condition that the SS troops left it in, with the burned remains of houses and businesses and their contents, including furniture, sewing machines, stoves, and other domestic items (Stone, 2004). This is how the town appeared when I first visited in I987, with bloodstains in the church and bullet holes in walls.

Soon after the war the town of Oradour-sur-Glane became a national memorial and a symbol of the brutality of the German occupation of France. The ruins were used as the site for political demonstrations and rallies by Gaullist parties and others. As a public memorial the ruins served a number of different purposes, not only for the survivors but for the nation as a whole coming to terms with a complicated legacy of defeat, occupation, collaboration, and resistance. Marion Stone's study of Oradour notes the key role played by French President Charles de Gaulle in promoting the site as a national memorial, chosen in part because it 'allowed a traumatized and humiliated nation to feel a sense of passive innocence and to take the victim's moral high ground' (Stone, 2004: I32).

Growing visitor numbers and the continuing erosion and decay of the ruins led to a growing concern with the stability of the site amongst survivors and their descendants, 


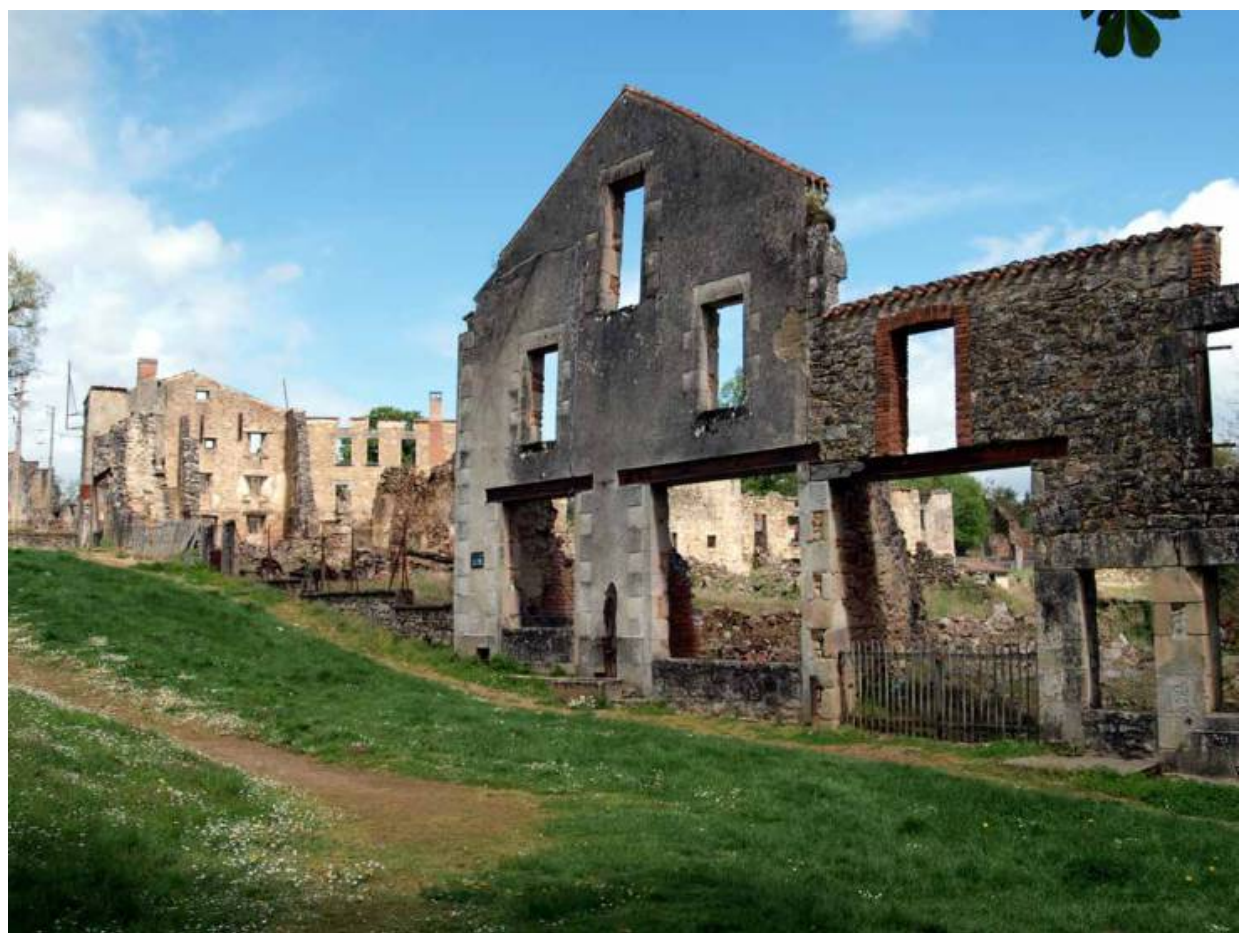

FIGURE 3 The facades of burnt buildings at Oradour-sur-Glane.

Source: Alf van Beem, Wikimedia Commons

leading to calls for a new form of commemoration at Oradour. This, together with a sense that the site would soon pass out of living memory, led to the creation of the new memorial centre that opened on the site in I999. This centre and the associated rise in visitor numbers required the conservation of the site in what one of the managers called 'the best possible state of ruin', with repair work to stabilize walls and other structures, some of which had collapsed to less than half of their post-war height. This curated condition has been described as 'a state of suspended but not disordered decay' (Steinmetz, 20I0: 303) (Figure 3).

The idea of 'the best possible state of ruin' is a problematic one, returning to the issues of authenticity and manipulation raised earlier in this paper. The changing audiences and political uses of Oradour in the years after 1944 have driven some of the changes, most notably in how the site is presented. Where earlier narratives focused on nationalistic propaganda and constructed senses of victimhood, the more recent visitor centre has attempted to place the massacre at Oradour within the context of genocides and crimes against humanity around the world (Stone, 2004). The question of authenticity is a difficult one for ruined sites like Oradour that base much of their appeal on the claim to offer unmediated, direct views of the horrors of war and violence. The promised visitor experience is visceral and emotionally charged, relying to some extent on this impression of authenticity, although the significance that visitors place on authenticity can vary considerably. Stone's study of the site 


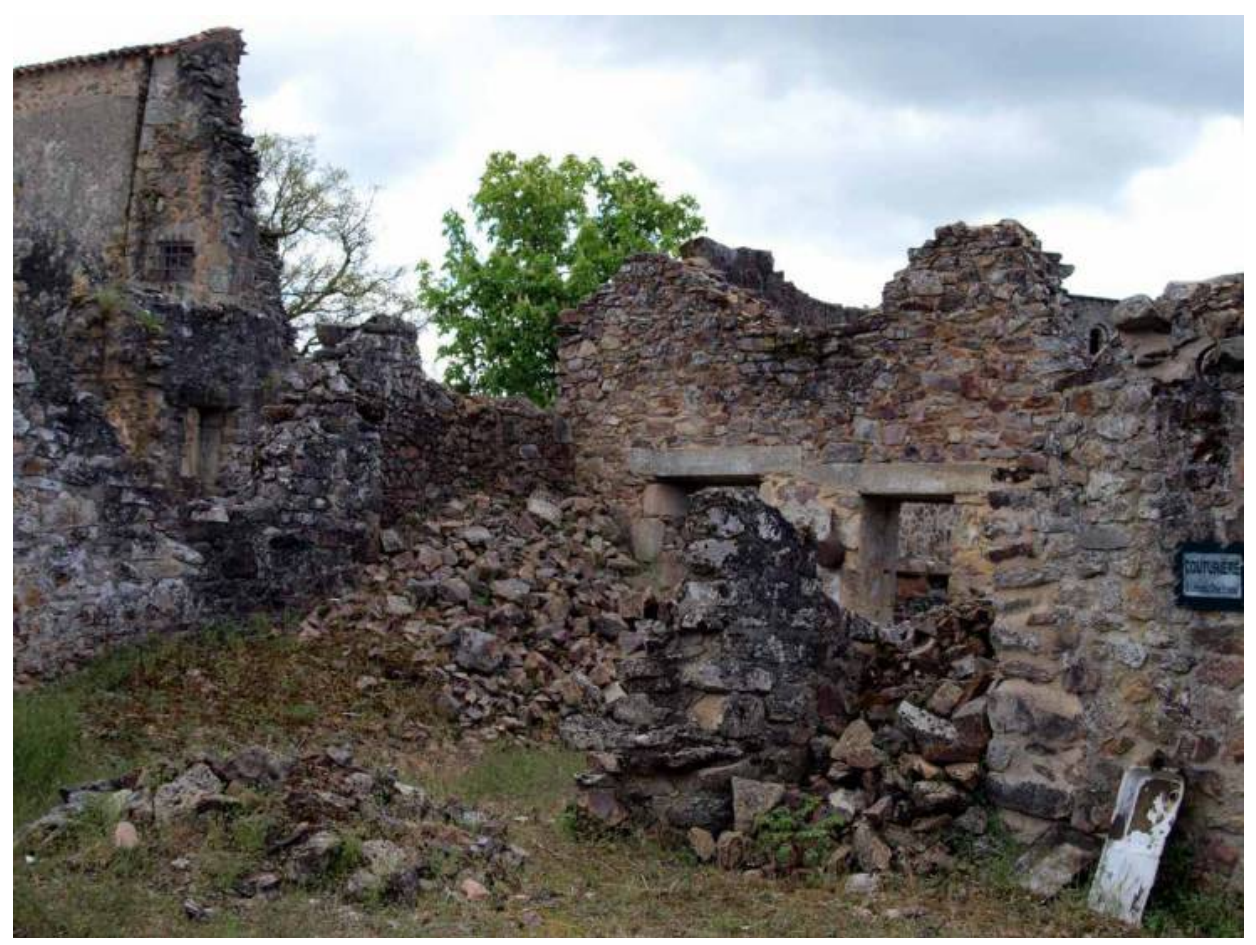

FIGURE 4 Collapsed walls and demolition rubble at Oradour-sur-Glane.

Source: Alf van Beem, Wikimedia Commons

included interviews with visitors, and suggested that most did not notice the artificial staging of objects, and few felt that it diminished in any way from the affective impact of the site.

Nonetheless the stabilization and conservation of ruins to give the impression of authenticity risks opening up memorial sites to accusations of fraud and the falsification of history. At Oradour there is evidence that objects inside the ruined homes such as children's toys have been added or moved to create a more emotionally powerful display: the 'better state of ruin' referred to earlier. Perhaps the lesson of Oradour (and one that site conservators and managers know well) is that even if there is no 'natural' material life of ruins to mirror political processes of reconciliation, there is still a lifecycle dictated by entropy and the ever-growing expenses of maintaining and stabilizing a site. As Thompson notes, 'however much solicitude may be lavished on a ruin, it has no indefinite life' (I98I: I0) (Figure 4).

\section{Discussion: ruins as cultural/political capital}

W.H. Auden wrote that 'Literary confessors are contemptible, like beggars who exhibit their sores for money, but not so contemptible as the public that buys their books' (I962: 99). Auden's simile highlights the source of my own discomfort with curated ruins: the sense that my natural emotional response to the material traces 
of human suffering is being somehow manipulated, whether for economic, social, or political ends. The theme of ruins as wounds on the body politic is a pervasive one in writings on war and conflict, and is one of the sources of the pervasive and (I would strongly argue) damaging idea that burned, blood-stained ruins will naturally fade into romantic, grass-covered ruins, or one of the other trajectories listed earlier.

Like the curated ruin, the curated wound has a long history. The priest and antiquarian Sabine Baring-Gould (best remembered as the author of the hymn Onward, Christian Soldiers) wrote an account of beggars that he encountered:

I have seen in the south of France a row of beggars sitting on the side of a bridge, day after day, winter and summer, showing sore legs and sore arms; these sores never get well, they were kept continually raw with caustic, in order to excite compassion, and obtain alms. And the most bitter jealousy reigned between these beggars as to the size and irritability of their respective sores. The man with only an inflamed knee burned with envy of the man whose whole leg was raw. Not for all the world would they let their wounds heal, as that would cut off from them a means of livelihood. (Baring-Gould, I876: I40-4I)

The case studies described above raise a number of questions around issues such as the implications of the pervasive wound-ruin metaphor for the understanding and responsible management of ruins as heritage resources; the links between material heritage, trauma, and healing; the political and cultural capital attached to narratives of victimhood; and the functions of ruins as memorials on local, national, and international scales. In embracing this thematic breadth alongside a personal/polemical approach, it is worth noting that this paper moves beyond and outside the traditional territory of debates around the management and conservation of heritage sites.

Ruins are commonly regarded and used as memorials, whether formally or informally and on a variety of scales from personal to international, and it is worth considering them in this light. My general rules for the interrogation of war memorials is to first ask which of the many parallel and divergent narratives of conflict the memorial is being used to promote. Following this I consider why this particular narrative is being promoted in this particular place, at this particular time or timeperiod, why the memorial has the form it has, and - finally — who most benefits from it. War memorials considered in this necessarily cynical and systematic fashion are first and foremost a form of cultural and political capital, and it is important that we also understand curated ruins through this lens. Ruins in any one specific form, time, and place hold a specific set of meanings: thus the ruins of Oradour in post-war France were (amongst other things) a means to promote collective national victimhood, and their value derived in part from this use. To have restored or removed the ruins of Oradour would have eliminated this source of cultural and political capital. This is illustrated by the example of the Frauenkirche, which was used by the East German regime as a focus for official anti-Western and unofficial anti-war propaganda campaigns. The restoration of the church soon after the collapse of the East German government eliminated the ruins as a source of political capital, specifically one associated with a widely disliked regime. The resistance to the reconstruction campaign focused on the more marginal, unofficial use of the Frauenkirche ruins' capital, but was outweighed by the perceived international cultural and political capital of a Frauenkirche restored through international cooperation between formerly 
belligerent nations. Sometimes the world changes and a ruin is found to hold the wrong form of (or not enough) capital. More often, on the other hand, it is the ruin that changes - as at Oradour, through erosion and decay — and to maintain its inherent capital it must be conserved and restored. Thus the curated ruin is first and foremost a managed form of capital, limited by its form and, in as far as it is contested, it is for control of the narratives that it can support and the uses to which it can be put.

Ruins are disorderly, anarchic spaces, but ruins-as-memorials are serious places of business, and to those engaged in such business I can offer some advice. In order to extract the greatest possible cultural and political capital from a war ruin one must firstly expel all children building microcosmic worlds, all pregnant cats, tadpoles, weeds (or flowers out-of-place), lizards, and nesting birds. The ruins must be silent and must not smell. Secondly, sculpt or dress the ruins into the form most conducive to their intended purpose and long-term stability, and present them thus as a supposedly authentic witness to a violent past. Thirdly and finally, if circumstances change and new forms of capital are required from the ruins, they may be further transformed, reconstructed, or removed, depending on the needs or whims of those with the power to control them and their message. No longer the manipulative beggars of conflict heritage, in this analysis curated ruins remain the tools of a more subtle but no less calculating set of agents intent on harnessing their capital in all its forms to further their assorted social, political, and economic ends.

\section{Acknowledgements}

An earlier version of this paper was presented at the inaugural meeting of the Association for Critical Heritage Studies in Gothenburg in June 20I2, in the session 'Deconstructing the Dark: a Critical Approach to Dark Heritage'. I am grateful to the session chairs and the conference organizers for the opportunity to present my work, and to the audience and other speakers at this event, as well as to the editors and referees for their comments and advice.

\section{Bibliography}

Auden, W.H. 1962. The Dyer's Hand. New York: Random House.

Baring-Gould, S. I876. Village Preaching for a Year. London: W. Skeffington and Son.

Davies, N. 2006. Rising '44: The Battle for Warsaw. London: Penguin.

de Keizer, M. 2013. The Thread that Binds Together: Lidice, Oradour, Putten, and the Memory of World War II. In: E. Langenbacher, B. Niven, and R. Wittlinger, eds. Dynamics of Memory and Identity in Contemporary Europe. Oxford: Berghahn, pp. I20-35.

Dillon, B. 20I4. Ruin Lust: Artists' Fascination with Ruins, from Turner to the Present Day. London: Tate.

Eshel, A. 20I0. Layered Time: Ruins as Shattered Past, Ruins as Hope in Israeli and German Landscapes and Literature. In: J. Hell and A. Schönle, eds. Ruins of Modernity. Durham: Duke University Press, pp. I33-50.

Farmer, S.B. I999. Martyred Village: Commemorating the 1944 Massacre at Oradour-sur-Glane. London: University of California Press.

Grayling, A.C. 2006. Among the Dead Cities: Was the Allied Bombing of Civilians in WWII a Necessity or a Crime? London: Bloomsbury.

Gutman, Y. 2009. Where Do We Go From Here: the Pasts, Presents and Futures of Ground Zero. Memory Studies, 2(I): 55-70. 
Huyssen, A. 2003. Present Pasts: Urban Palimpsests and the Politics of Memory. Stanford: Stanford University Press.

James, J. 2006. Undoing Trauma: Reconstructing the Church of Our Lady in Dresden. Ethos, 34(2): $244-72$.

Jordan, J.A. 2006. Structures of Memory: Understanding Urban Change in Berlin and Beyond. Stanford: Stanford University Press.

Keegan, J. 1989. The Second World War. London: Penguin.

Lambourne, N. 200I. War Damage in Western Europe: The Destruction of Historic Monuments During the Second World War. Edinburgh: Edinburgh University Press.

Lindqvist, S. 200I. A History of Bombing. London: Granta.

Macauley, R. 1953. Pleasure of Ruins. New York: Barnes \& Noble.

Meskell, M. 2002. Negative Heritage and Past Mastering in Archaeology. Anthropological Ouarterly, 75(3): 557-74.

Moshenska, G. 2009. Resonant Materiality and Violent Remembering: Archaeology, Memory and Bombing. International Iournal of Heritage Studies, I $5(\mathrm{I}): 44^{-5} 6$.

Moshenska, G. 20Io. Working with Memory in the Archaeology of Modern Conflicts. Cambridge Archaeological Journal, 20(I): 33-48.

Moshenska, G. 20I4. Children in Ruins: Bombsites as Playgrounds in Second World War Britain. In: B. Olsen and P. Pétursdóttir, eds. Ruin Memories: Materiality, Aesthetics and the Archaeology of the Recent Past. Abingdon: Routledge, pp. $230-48$.

Nora, P. 1989. Between Memory and History: Les Lieux de Mémoire. Representations, 26: 7-25.

Rico, T. 2008. Negative Heritage: The Place of Conflict in World Heritage. Conservation and Management of Archaeological Sites, $10(4): 344-52$.

Roth, M.S., Lyons, C., \& Merewether, C. I997. Irresistible Decay: Ruins Reclaimed. Los Angeles, CA: Getty Research Institute.

Schaffer, R. 2009. The Bombing Campaigns in World War II: The European Theatre. In: Y. Tanaka and M.B. Young, eds. Bombing Civilians: A Twentieth Century History. London: The New Press, pp. 30-45.

Steinmetz, G. 20I0. Colonial Melancholy and Fordist Nostalgia: The Ruinscapes of Namibia and Detroit. In: J. Hell and A. Schönle, eds. Ruins of Modernity. Durham: Duke University Press, pp. 294-320.

Stone, M. 2004. A Memory in Ruins? Public Archaeology, 3: I3 I-44.

Taylor, F. 2005. Dresden: Tuesday I3 February 1945. London: Bloomsbury.

Thompson, M.W. 198I. Ruins: Their Preservation and Display. London: British Museum.

Tiratsoo, N. 2000. The Reconstruction of Blitzed British Cities 1945-55: Myths and Reality. Contemporary British History, I4(I): 27-44.

Tumarkin, M. 2005. Traumascapes: The Power and Fate of Places Transformed by Tragedy. Carlton: Melbourne University Press.

Winter, J. 2006. Remembering War: The Great War Between Memory and History in the Twentieth Century. London: Yale University Press.

Woodward, C. 2002. In Ruins. London: Vintage.

\section{Notes on contributor}

Gabriel Moshenska is Lecturer in Public Archaeology at UCL Institute of Archaeology. His research interests include multidisciplinary approaches to the heritage of recent conflicts, the public understanding of the past, the intellectual history of archaeology, and the use of archaeological themes in fantasy and horror fiction. He is the author of The Archaeology of the Second World War: Uncovering Britain's Wartime Heritage (Pen \& Sword, 20I2).

Correspondence to: Gabriel Moshenska. Email: g.moshenska@ucl.ac.uk 